\title{
Immunological Studies of Amination Deficient Strains of Neurospora crassa
}

\author{
By D. B. ROBERTS and J. A. PATEMAN \\ Department of Genetics, University of Cambridge
}

(Received 2 August 1963)

\begin{abstract}
SUMMARY
A survey has been made of the immunological relationships between glutamate dehydrogenase (GDH) and the related proteins of the amination deficient (am) mutants of Neurospora crassa. Serum against GDH was prepared in rabbits which had been injected with crude extracts of wild type $N$. crassa. The effect of this serum on the activity of normal GDH and the activity of activated mutant proteins was studied. The techniques of double diffusion in agar gel and of immunoelectrophoresis were used to study the relationships between the wild-type GDH and mutant forms of the protein. The identification of the relevant precipitation line on these gel plates was confirmed by the use of a specific stain for the enzyme antibody complex. The relationship between the antigenic and enzymic sites in the wild-type protein is discussed.
\end{abstract}

\section{INTRODUCTION}

Nineteen independent occurrences of a mutation at the am locus in Neurospora crassa are known. The am mutants require exogenous $\alpha$-amino acids for normal growth and lack normal NADP (nicotinamide adenine dinucleotide phosphate)linked glutamate dehydrogenase activity. Two previous immunological surveys of the relationships between the wild GDH and the proteins formed by the am mutants 1-8 have been carried out (Barratt, 1962; Sanwal \& Lata, 1962). Some of the results of Sanwal \& Lata (1962) differ from the results presented in this paper. This difference may have been due to techniques used; however, it now seems that the results in the present paper are the best description of the situation (Dr B. D. Sanwal, pers. commun.). The present survey repeats the previous surveys using different techniques and includes a further eleven mutants. Mutants 1-13, with the exception of 10 , have recently been crossed with each other (Pateman, unpublished results). No mutant crossed with itself gave wild-type recombinants and with two exceptions all crosses between mutants gave detectable frequency of wild-type recombinants. From enzyme studies and the crossing data it was concluded that mutants 1-9, 11 and 13 are each the result of mutation at different genetic sites. No wild-type recombinants were recovered from the cross between $a m-3$ and $a m-12$ or from the cross between $a m-7$ and $a m-13$. Consequently in each case the pairs of mutants are considered to be independent occurrences of a mutational event at the same genetic site. 


\section{METHODS}

Neurospora strains. The stock wild-type was basically St Lawrence 74. A (Pateman, 1959); am mutants 1-11 were described by Fincham (1959). Mutants am 12 and 13 were induced by ultraviolet (u.v.) irradiation in the laboratory of Dr J. R. S. Fincham. The mutants am 14-19 were induced with nitrous acid by Dr D. Stadler.

Growth of cultures. For purification and preparation of antigen solutions for injection into rabbits, a culture of the strain was grown for one week on $300 \mathrm{ml}$. Vogel minimal medium (H. J. Vogel, Microbial Genetics Bulletin, no. 13) with $2 \%$ agar in a 1 l. culture flask at $25^{\circ}$. The conidia were harvested by washing the surface of the culture with $100 \mathrm{ml}$. sterile water. This suspension was poured into $15 \mathrm{l}$. Vogel minimal medium in a $20 \mathrm{l}$. flask and the culture incubated for 16-18 hr at $30^{\circ}$ with vigorous aeration. The mycelium was harvested on muslin, washed thoroughly with distilled water, blotted dry (about 100-200 g. blotted mycelium was usually obtained), cut into small pellets and stored at $-20^{\circ}$ until required.

For testing, the strain was grown on $150 \mathrm{ml}$. liquid medium in a 1 l. culture flask for $40 \mathrm{hr}$ at $\mathrm{25}^{\circ}$. The mycelial pad was sucked dry on a small Buchner funnel after washing with distilled water, then blotted dry and kept at $-20^{\circ}$ until required. The medium for the wild-type fungus was Vogel minimal medium. The mutants were grown on Vogel minimal supplemented with either M/200 DL-alanine or M/400 Lglutamic acid sodium salt at $25^{\circ}$. In special cases the mutants were grown on minimal medium at $37^{\circ}$.

Preparation of extracts. Extracts for purification or injection were prepared in an MSE Atomix blender (Fincham, 1962). The frozen powder for purification was stirred into $0.05 \mathrm{M}$-sodium orthophosphate buffer ( $\mathrm{pH} \mathrm{8.0)}$ ) with $0.001 \mathrm{~m}$-ethylenediaminetetra-acetic acid (EDTA) added. The powder for injection was stirred into $0 \cdot 02 \mathrm{M}$-sodium orthophosphate buffer $(\mathrm{pH} 7 \cdot 2)$. Both extracts were centrifuged for $30 \mathrm{~min}$. at $3,000 \mathrm{~g}$, then filtered under pressure through a $35 \mathrm{~g}$. pad of kieselguhr on a $12 \mathrm{~cm}$. Buchner funnel. These were crude extracts.

Extracts for testing were prepared by grinding with a pestle in a mortar with ground glass and buffer (0.05 M-sodium orthophosphate $(\mathrm{pH} \mathrm{8.0)}$ with $0.001 \mathrm{M}$ EDTA for extracts studied enzymatically and $0.02 \mathrm{M}$-buffer $(\mathrm{pH} 7 \cdot 2$ ) for extracts studied in gel plates). The resulting slurry was either filtered under pressure through a $4 \mathrm{~g}$. pad of kieselguhr on a small Buchner funnel (extracts studied enzymatically) or centrifuged for $30 \mathrm{~min}$. at about $37,000 \mathrm{~g}$, in an MSE 25 centrifuge (extracts studied in gel plates). In most cases the extracts were made of $1 \mathrm{~g}$. blotted mycelium to $3 \mathrm{ml}$. buffer.

Purification. The crude extract was purified by the method of Fincham (1962).

Enzyme assays. Enzyme activities were measured by the methods of Fincham (1962), following either the reduction of nicotinamide adenine dinucleotide phosphate (NADP) or the oxidation of reduced NADP $\left(\mathrm{NADPH}_{2}\right)$ by optical density measurements at $340 \mathrm{~m} \mu$.

The reaction mixture for wild-type enzyme was $0.2 \mathrm{ml} .0 .5 \mathrm{M}-\mathrm{L}$-glutamic acid sodium salt, $0.2 \mathrm{ml}$. $0.2 \% \mathrm{NADP}$, enzyme, made up to $3 \mathrm{ml}$. with $0.05 \mathrm{M}$-tris $\mathrm{HCl}$ (pH 8.4) buffer. The enzyme assay was carried out in a $1 \mathrm{~cm}$. silica cell in a Unicam S.P. 500 spectrophotometer with the cell housing maintained at $35^{\circ}$ by circulating 
water. Activities are expressed as the change in optical density at $\mathbf{3 4 0} \mathrm{m} \mu, \times 1000$. To assay the background, if any, a control run was made in which the reaction mixture was completed by the addition of glutamate; readings for the $2 \mathrm{~min}$. before addition of glutamate gave the background activity. The standard assays were started by adding NADP, the background from the control run being subtracted. In the experiments to be discussed the serum was incubated with the reaction mixture without NADP : other experiments to be reported elsewhere showed that in the case of the wild-type enzyme neither the glutamate nor the NADP affected the inhibition of the enzyme activity by the treated serum. In the series of experiments with mutant $a m-2 \quad 0 \cdot 2 \mathrm{ml} .2 \mathrm{M}-\mathrm{L}$-glutamic acid sodium salt was used.

The reaction mixture used when studying the oxidation of $\mathrm{NADPH}_{2}$ was: $0.1 \mathrm{ml}$. 0.2 M-disodium $\alpha$-oxoglutarate in $0.4 \mathrm{~N}-\mathrm{NaOH} ; 0.1 \mathrm{ml} .0 .2 \mathrm{M}-\mathrm{NH}_{4} \mathrm{Cl} ; 0.1 \mathrm{ml}$. $0.2 \% \mathrm{NADPH}_{2}$; enzyme; made up to $3 \mathrm{ml}$. with $0.1 \mathrm{M}$-sodium orthophosphate buffer ( $\mathrm{pH} \mathrm{8.0)}$ and assayed at $20^{\circ}$. Background was assessed by taking readings before the reaction was started with the $\mathrm{NH}_{4} \mathrm{Cl}$. The serum was incubated with reaction mixture lacking $\mathrm{NADPH}_{2}$ and $\mathrm{NH}_{4} \mathrm{Cl}$ at $35^{\circ}$ and then cooled to $20^{\circ}$ before assay.

Protein estimations. The protein concentration of the purified preparations from the diethylaminoethyl cellulose (DEAE) columns was estimated by multiplying the optical density at $280 \mathrm{~m} \mu$ by $1 \cdot 10$ (Fincham, 1962). All other protein concentrations were by the method of Lowry, Rosebrough, Farr \& Randall (1951) with reference to a standard curve prepared with casein.

Preparation of antibodies against glutamate dehydrogenase. Each series of three rabbits (New Zealand Whites) was given an intraperitoneal injection of $10 \mathrm{ml}$. antigen preparation (crude wild-type extract in series B, purified GDH in series C) and an intramuscular injection of antigen mixed with an equal volume of Freund's adjuvant, giving a final volume of $5 \mathrm{ml}$. Each series of rabbits was given intramuscular injections 1 and 2 weeks later and bled 1 week after the last injection. Before each subsequent bleeding the series was given 2-weekly intramuscular injections and bled 1 week later. As far as possible this programme was always used. The series, rabbit and bleed are indicated thus: B-2-3 means the third bleed from the second rabbit in series $B$. In this paper all antibodies will be referred to as anti$\mathrm{am}^{+}$antibodies, that is antibodies against the wild-type glutamate dehydrogenase. The blood was allowed to clot at room temperature overnight, the serum poured off, centrifuged, divided into samples which were stored at $-20^{\circ}$ until required.

Double-diffusion plates. The double-diffusion plates were a modification of the technique developed by Ouchterloney (1953), by using the method of preparation described by Coombs, Richards \& Dodd (1963).

Immunoelectrophoretic plates. The immunoelectrophoretic plates were a modification of the technique of Grabar \& Williams (1955). A sample (10 g.) of Noble special agar (Difco Laboratories, Detroit, Michigan, U.S.A.) was washed and made up to $500 \mathrm{ml}$. with $0.06 \mathrm{M}$-barbital buffer ( $\mathrm{pH} 8.6 ; 1.84 \mathrm{~g}$. barbituric acid, $10 \mathrm{~g}$ sodium barbitone in 1 1.). The agar was dissolved and after filtering divided into $5 \mathrm{ml}$. samples. To prepare the plates one vial of agar was melted and $5 \mathrm{ml}$. distilled water added, to give a $1 \%$ agar gel and altering the molarity of the buffer to $0.03 \mathrm{M}$. The plates were stored in plastic boxes containing wet lint, and holes in the agar cut with a cork borer; the slots were cut with a mapping pen. When the holes had been 
filled with antigen the plate was placed in an electrophoresis tank (Shandon Scientific Co., London) and connected to the buffer compartment with lint wicks. The buffer used was $0.06 \mathrm{M}$-barbital buffer ( $\mathrm{pH} \mathrm{8.6)}$ ). A potential difference of $150 \mathrm{~V}$. was maintained on a Shandon power-pack (type 2540) for $45 \mathrm{~min}$.; this gave a voltage drop across a single plate of 50-60 V. After electrophoresis the slots were cut and filled with serum. The plates were then stored as before for diffusion and precipitation to take place.

Staining. Clearing, drying and staining for all proteins was carried out as described by Coombs et al. (1963).

Stain for $\boldsymbol{G D H}$ or $\boldsymbol{A D H}$ anti-am+ serum complexes. The staining technique used to locate the GDH and ADH anti- $\mathrm{am}^{+}$serum complex in double diffusion and immunoelectrophoresis plates was an adaptation of the general staining method for dehydrogenases used by Markert \& Møller (1959). The staining technique can be used with any reaction which reduces NADP. Hydrogen from the $\mathrm{NADPH}_{2}$ is carried to the neotetrazolium chloride which is reduced to an insoluble formazan dye in the region of the reaction.

(a) Reaction mixture for GDH anti-am ${ }^{+}$serum complex. After clearing, the slides were immersed in a reaction mixture of $5 \mathrm{ml} .0 \cdot 05 \mathrm{M}$-tris buffer ( $\mathrm{pH} \mathrm{8.0}$ ), 0.4 $\mathrm{ml}$. 0.05 M-hydrazine dihydrochloride (adjusted to $\mathrm{pH} \mathrm{7-8}$ with $\mathrm{s}-\mathrm{NaOH}$ ), $1 \mathrm{mg}$. NADP, $1.5 \mathrm{mg}$. neotetrazolium chloride, $0.5 \mathrm{mg}$. phenazine methosulphate, $85 \mathrm{mg}$. Na-L-glutamate. The surface of the reaction mixture was covered with paraffin to exclude oxygen and the whole incubated at $37^{\circ}$ for $5 \mathrm{~min}$. The slide was washed in distilled water, dried and varnished with Ercalene varnish (Canning and Co. Ltd., Birmingham).

(b) Reaction mixture for ADH anti-am+ serum complex. The reaction mixture for $\mathrm{ADH}$ was as above except that $0.05 \mathrm{M}$-tris buffer ( $\mathrm{pH} \mathrm{9.0)}$ ) was used and $135 \mathrm{mg}$. L-alanine instead of glutamate. Since this reaction is much slower the reaction mixture was incubated for $50-60 \mathrm{~min}$. at $37^{\circ}$. The slides were then treated as above.

\section{RESULTS}

\section{Enzyme inhibition}

In all the experiments discussed below with anti- $a m^{+}$serum, a control was done with serum from untreated rabbits. Under no condition tested did the presence of control serum affect the enzyme activity or the reaction mixture without enzyme.

To test the inhibition of GDH activity, serum was incubated at $35^{\circ}$ for $30 \mathrm{~min}$. with the enzyme and reaction mixture without NADP. The activities of constant amounts of enzyme incubated with differing amounts of anti-am ${ }^{+}$serum are expressed as the increase in optical density at $340 \mathrm{~m} \mu \times 1000$ in the 1 st min. of the reaction (Fig. 1).

An experiment was made to determine whether the $\mathbf{3 0} \mathrm{min}$. incubation of enzyme with serum was sufficient for the serum to have its full effect on the enzyme. Constant amounts of enzyme were incubated for various times at $35^{\circ}$ with sufficient serum to decrease the enzyme activity to about $40 \%$. It seems that the serum exhibited its full inhibitory effect within the first $25 \mathrm{~min}$. (Fig. 2). Similar inhibition of enzyme activity was observed when the enzyme was incubated with the anti-am ${ }^{+}$ serum and then assayed by following the oxidation of $\mathrm{NADPH}_{2}$ (Fig. 3). 
Some of the am mutant glutamate dehydrogenase proteins can be activated by substrate and subsequently catalyse the reduction of NADP (Fincham, 1962). Two of these mutant proteins were studied to see whether the $\mathrm{am}^{+}$serum would inhibit this activated catalytic activity. The enzyme from am-2 showed about a third of wild-type activity when four times the normal amount of glutamate was used and even more activity when it was incubated with glutamate before the reaction was started. Enzyme am-3 can be activated by substrate incubation and at high concentrations of substrate (four times normal) showed greater activity than did the wildtype GDH. The studies on $a m-2$ are discussed below, $a m-3$ showed a complicated

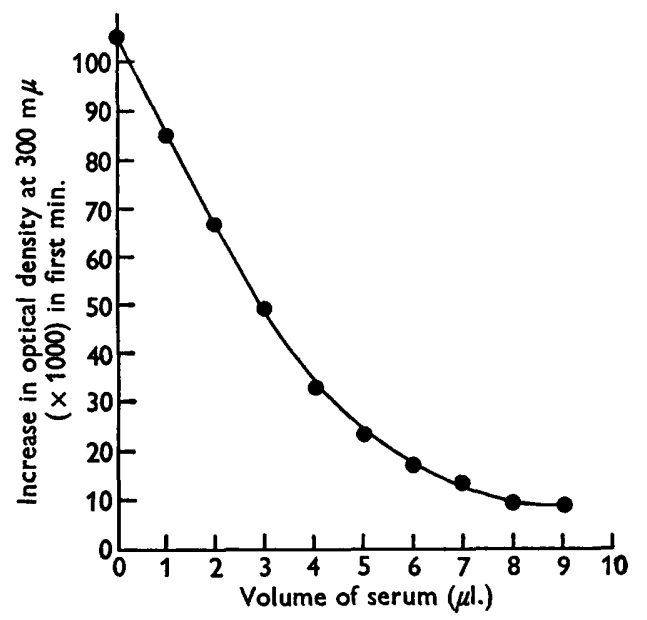

Fig. 1

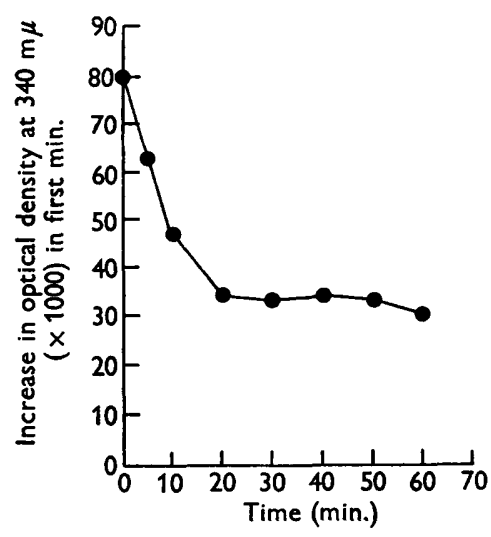

Fig. 2

Fig. 1. Effect of serum concentrations on the activity of wild-type GDH enzyme. Reaction mixture: $2.5 \mathrm{ml}$. 0.05 M-tris buffer ( $\mathrm{pH} \mathrm{8.4);0.1} \mathrm{ml.} \mathrm{crude} \mathrm{wild-type} \mathrm{extract;}$ serum B-1-9 incubated for $30 \mathrm{~min}$; $0.2 \mathrm{ml} .0 .2 \%$ NADP added. Readings taken on a spectrophotometer for background activity; $0.2 \mathrm{ml}$. $0.2 \mathrm{M}-\mathrm{Na}$ L-glutamate added. The background activity was subtracted from the activity in the 1st min. Incubation and assay at $85^{\circ}$. Wild-type extract protein concentration $1.2 \mathrm{mg} . / \mathrm{ml}$.

Fig. 2. Effect of incubation time on the inhibition of GDH enzyme activity by a constant amount of serum. Reaction mixture: $2.5 \mathrm{ml}$. 0.05 M-tris buffer (pH 8.4); 0.05 ml. crude wild-type extract; 0.05 ml. B-1-4 serum; 0.02 ml. 0.2 M-Na L-glutamate; incubated for different times at $35^{\circ}$. The assay was started by the addition of $0.2 \mathrm{ml} .0 .2 \%$ NADP.

interaction with anti-am ${ }^{+}$serum (details to be published). However, the initial experiments showed it to possess a protein immunologically similar to wild-type GDH. A preliminary study of am-2 showed that its enzyme activity was inhibited by anti-am ${ }^{+}$serum (Table 1 ).

The majority of am mutants, however, do not produce any kind of glutamate dehydrogenase activity. Consequently any relationship between them and the anti- $a m^{+}$serum had to be studied indirectly. Experiments were done to see whether these am mutants produced any protein capable of inhibiting the inhibitory activity of the serum on wild-type GDH. Mutant extracts were incubated for $30 \mathrm{~min}$. at $35^{\circ}$ with serum in the reaction mixture less NADP. Enzyme was then added and the reaction started, after a further 30 min. incubation, with NADP. Controls were run with control serum and incubation of anti- $\mathrm{am}^{+}$serum with buffer for $30 \mathrm{~min}$. before 
Table 1. A comparison of the effect of anti-am ${ }^{+}$serum on $a^{+}$and am-2 extracts

\begin{tabular}{|c|c|c|c|}
\hline & & \multicolumn{2}{|c|}{$\begin{array}{l}\text { Increase in optical density } \\
10^{3} \text { at } 340 \mathrm{~m} \mu \text { in the 1st } \mathrm{m}\end{array}$} \\
\hline & & $a m^{+}$ & $a m-2$ \\
\hline Expt. 1 & $\begin{array}{l}\text { Control serum } \\
\text { B-3-3 }\end{array}$ & $\begin{array}{l}80 \\
19\end{array}$ & $\begin{array}{l}30 \\
11\end{array}$ \\
\hline Expt. 2 & $\begin{array}{l}\text { Control serum } \\
\text { B-3-3 }\end{array}$ & $\begin{array}{l}85 \\
17\end{array}$ & $\begin{array}{r}29 \\
9\end{array}$ \\
\hline
\end{tabular}

$0.05 \mathrm{ml}$. of serum; $0.025 \mathrm{ml}$. of $\mathrm{am}^{+}$and $\mathrm{am-2}$ extracts; $0.2 \mathrm{ml}$. $2 \mathrm{M}-\mathrm{Na}-\mathrm{L}-$ glutamate in these assays. $\mathrm{am}^{+}$extract $4 \cdot 3 \mathrm{mg}$. protein $/ \mathrm{ml}$., am-2 extract $5 \cdot 15 \mathrm{mg}$. protein $/ \mathrm{ml}$.

Table 2. The effect of extracts of Neurospora crassa mutants am-4 and am-5 on the inhibitory activity of anti-am ${ }^{+}$serum

The sera were incubated at $35^{\circ}$ for $25 \mathrm{~min}$. in $2.55 \mathrm{ml}$. of tris buffer and $0.2 \mathrm{ml} .0 .5 \mathrm{M}$ Na-L-glutamate with buffer or $a m-4$ or $a m-5$, the final volume being about $2 \cdot 8 \mathrm{ml}$. Crude wild-type extract $(25 \mu \mathrm{l}$.) was then added and the mixture incubated for a further $25 \mathrm{~min}$. The reaction was assayed at $35^{\circ}$ and started by the addition of $0.2 \mathrm{ml}$. of $0.2 \%$ NADP. The table shows that am-4 protected wild-type GDH activity from inhibition by the anti- $a m^{+}$serum while $a m-5$ did not.

Protein concentrations: 5.0 mg. wild/ml., 5.5 mg. am-4/ml., 5.35 mg. $a m-5 / \mathrm{ml}$.

\begin{tabular}{|c|c|c|c|c|}
\hline $\begin{array}{c}\text { Control serum } \\
(\mu \mathrm{l} .)\end{array}$ & $\begin{array}{c}\text { B-3-4 anti-am }{ }^{+} \\
\text {serum } \\
(\mu \mathrm{l} .)\end{array}$ & $\begin{array}{l}\text { Crude } a m-4 \\
\quad(\mu \mathrm{l} .)\end{array}$ & $\begin{array}{l}\text { Crude } a m-5 \\
\quad(\mu 1 .)\end{array}$ & $\begin{array}{c}\text { Activity. } \\
\text { Increase in } \\
\text { optical density } \\
\times 10^{3} \text { at } \\
340 \mathrm{~m} \mu \text { in } \\
\text { 1st min. }\end{array}$ \\
\hline $2 \cdot 5$ & - & - & - & 100 \\
\hline $2 \cdot 5$ & - & 25 & - & 98 \\
\hline- & $2 \cdot 5$ & - & - & 46 \\
\hline- & $2 \cdot 5$ & 25 & - & 91 \\
\hline $6 \cdot 25$ & - & - & - & 106 \\
\hline $6 \cdot 25$ & - & 25 & - & 98 \\
\hline- & $6 \cdot 25$ & - & - & 33 \\
\hline- & 6.25 & 25 & - & 86 \\
\hline 5 & - & - & - & 108 \\
\hline 5 & - & - & 25 & 106 \\
\hline- & 5 & - & - & 24 \\
\hline- & 5 & - & 25 & 27 \\
\hline $\mathbf{3}$ & - & - & - & 118 \\
\hline 3 & - & - & 25 & 112 \\
\hline- & $\mathbf{3}$ & - & - & 35 \\
\hline- & 3 & - & 25 & 36 \\
\hline
\end{tabular}

incubation with wild-type enzyme. The results for two mutants are given in Table 2. It can be seen that the $a m-5$ extract had no effect on the anti-am ${ }^{+}$serum, which inhibited wild-type enzyme activity as much in the presence of $a m-5$ extract as in the presence of buffer only. The $a m-4$ extract on the other hand protected the wild-type enzyme from inhibition by the anti- $a m^{+}$serum.

Similar results were obtained from experiments with the oxidation of $\mathrm{NADPH}_{2}$ assay system. In these experiments mutant $a m-1$ and $a m-11$ were used. The mutant 
extract was incubated at $35^{\circ}$ for $30 \mathrm{~min}$., with anti- $\mathrm{am}^{+}$serum, in the reaction mixture without $\mathrm{NADPH}_{2}$ and $\mathrm{NH}_{4} \mathrm{Cl}$. The $\mathrm{am}^{+}$extract was then added and incubated for another $30 \mathrm{~min}$. The mixture was cooled to $20^{\circ}$ and $\mathrm{NADPH}_{2}$ added; the reaction was started with $\mathrm{NH}_{4} \mathrm{Cl}$. The am-1 extract protected the wild-type enzyme by inhibiting the anti-am ${ }^{+}$serum (Fig. 3). The $a m-11$ extract on the other hand did not protect the wild-type enzyme from the serum (Fig. 4).

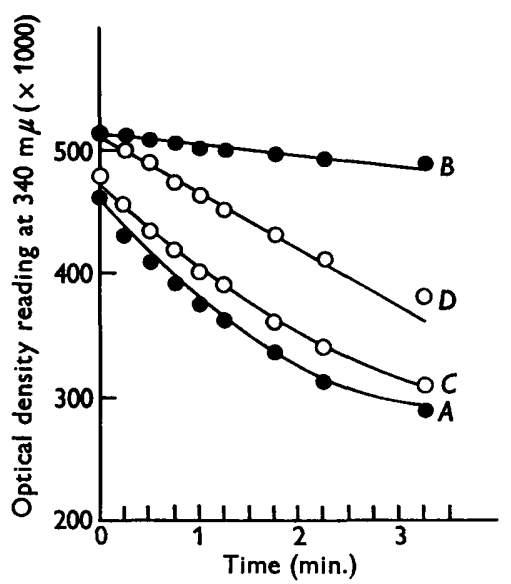

Fig. 3

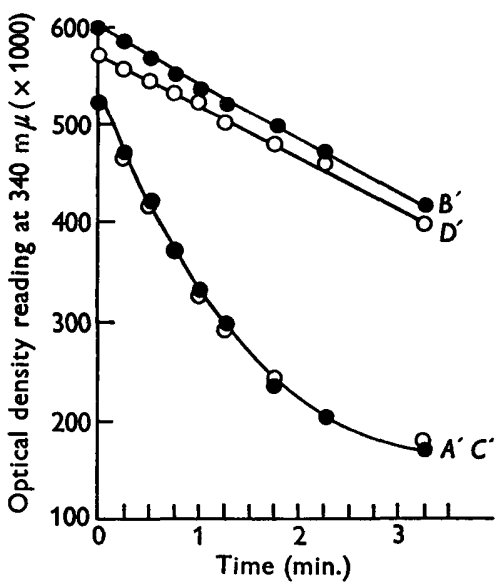

Fig. 4

The protection of wild-type enzyme activity from the inhibitory activity of the anti-am+ serum by $a m-1$ and $a m-11$ extracts.

Fig. 3. Curve $A$ shows the activity of $0.01 \mathrm{ml}$. of crude wild-type extract incubated for $30 \mathrm{~min}$. with control serum after the serum had been incubated for $30 \mathrm{~min}$. with $2.6 \mathrm{ml}$. tris buffer (pH 8.4) and $0.1 \mathrm{ml}$. of $0.2 \mathrm{M}-\alpha$-oxoglutarate. The reaction was started by adding $0.1 \mathrm{ml} .0 \cdot 2 \% \mathrm{NADPH}_{2}$ followed by $0.1 \mathrm{ml} .0 .2 \mathrm{M}-\mathrm{NH}_{4} \mathrm{Cl}$. Curve $B$ shows the activity of crude wild-type extract as above in the presence of anti-am ${ }^{+}$serum B-2-3. Curve $C$ shows the activity of crude wild-type extract where control serum was incubated for $30 \mathrm{~min}$. with $0.01 \mathrm{ml}$. am-1 extract before the addition of wild-type extract. Curve $D$ shows the activity of crude wild-type extract where the anti-am+ serum was incubated with $a m-1$ before addition of wild-type extract.

Fig. 4. Curves $A^{\prime}, B^{\prime}, C^{\prime}, D^{\prime}$ as for $A, B, C, D$, in Fig. 3, but with am-11 extract instead of $a m-1$ extract.

The am-3 protein, which shows a complicated interaction with the anti-am+ serum in the NADP system, cannot be activated and assayed by studying the oxidation of $\mathrm{NADPH}_{2}$. However it protected the wild-type enzyme from the activity of the anti-am ${ }^{+}$serum when the reactions were studied as above; that is it showed the same properties as the $a m-1$ protein.

Six of the mutants have been studied by using these methods. The $a m-1, a m-2$, $a m-3$ and $a m-4$ proteins showed immunological similarity to the wild-type enzyme in that they were able to react with the anti-am+ serum. It is not known whether $a m-5$ or $a m-11$ produced a mutant GDH protein or not. If they did this protein showed no immunological similarity to the wild-type enzyme. With the methods outlined above, they did not react in any detectable way with the anti-am ${ }^{+}$serum. 


\section{Double diffusion gel plates}

Gel plates were set up to determine the immunospecificity of the wild-type enzyme and the proteins made by the mutants. Plate 1, figs. 1, 2, show the reactions between anti-am ${ }^{+}$serum and purified GDH, a crude extract of wild-type enzyme, and a crude extract of $a m-11$. The reaction between purified GDH and antibody gave rise to two precipitation lines, the stronger one being presumed to be that due to GDH. This antigen was also present in the crude wild-type extract but not in the am-11 extract.

To remove any doubt as to the identity of the GDH anti-am ${ }^{+}$serum precipitation line it was stained for GDH activity. Fincham (1962) previously used this stain to identify the GDH band in starch gel after electrophoresis. Because the enzyme retained a certain degree of activity even with high quantities of serum (Fig. 1) it seemed possible that the antigen + antibody precipitates might show some activity. When washed plates with the GDH anti-am+ serum line were immersed in the reaction mixture for 5-10 min. and incubated at $37^{\circ}$, one of the lines on the plate became stained. The stained line was the line that had been called the GDH anti$\mathrm{am}^{+}$serum line on the basis of the previous experiment. This evidence identifies without doubt the GDH anti-am+ serum line and shows that the line missing in the case of some of the mutants is the relevant line and not a line due to another system (Pl. 1, figs. 3 and 4 ).

\section{Immunoelectrophoresis plates}

Experiments were made with immunoelectrophoretic techniques; on these plates the antigens were placed in wells and a potential difference maintained across the plate for $45 \mathrm{~min}$. This gave an electrophoretic separation of the proteins. Slots were cut in the agar parallel to the direction of electrophoresis and filled with serum; diffusion of antigens and antibodies took place, giving precipitation arcs in the gel. Again certain mutants lacked one line and this line was the prominent line in the purified GDH preparation. The plates were stained for glutamate dehydrogenase activity: the suspected GDH anti-am+ serum line was the line stained. It was thus possible to identify the relevant line on the plates.

\section{Alanine dehydrogenase}

Bürk \& Pateman (1962) showed that GIJH also possessed alanine dehydrogenase $(\mathrm{ADH})$ activity. Double-diffusion plates were used to see whether the GDH anti$a m^{+}$serum line was also the ADH anti- $a m^{+}$serum line. Since ADH can react using NADP and alanine, the staining reaction mixture was changed in order to stain the ADH anti- $\mathrm{am}^{+}$serum complex on the plates. The ADH activity is about $0.1 \%$ of the GDH activity under these conditions. Consequently the plates were incubated at $37^{\circ}$ for $50-60 \mathrm{~min}$. In spite of the quantity of background stain that could not be washed from the plates, one line was stained. This was the line previously determined as the GDH anti-am+ line (Pl. 1, fig. 5).

\section{Substrate inhibition}

It was possible that alanine or glutamate in the medium used for growing the am mutants inhibited the production of mutant protein in certain of the mutants. 
Wild-type and $a m-6$ strains were used in experiments designed to test this possibility. These strains were grown up on medium containing $\mathrm{M} / 200 \mathrm{DL}-$ alanine and medium containing $\mathrm{M} / 400 \mathrm{~L}$-glutamate at $25^{\circ}$ and on minimal medium at $37^{\circ}$. Extracts of the resulting mycelia were tested on double-diffusion plates for GDH anti-am ${ }^{+}$serum complex, against purified GDH and crude extracts of wild-type strain grown on Vogel minimal medium at $25^{\circ}$. Under all these conditions the wildtype strain possessed the GDH anti- $\mathrm{am}^{+}$serum line and under none of the conditions did the mutant am-6 produce an immunologically similar protein.

\section{DISCUSSION}

The sera from rabbits injected with crude extracts of the soluble proteins of Neurospora crassa inhibit the activity of glutamate dehydrogenase. It seems that incubation at $\mathbf{3 5}^{\circ}$ for $30 \mathrm{~min}$. is sufficient time for the antibodies to have their full effect on the enzyme activity. In the reaction mixture studied with the spectrophotometer high concentrations of serum did not completely inhibit the enzyme activity. The enzyme anti-am ${ }^{+}$serum complex on double-diffusion plates still showed activity in that it was capable of reducing NADP to $\mathrm{NADPH}_{2}$. That is, the complexes of GDH + antibody molecules still retained enzyme activity. The enzymatic site may not coincide with any antigenic site, in which case the inhibition

Table 3. Summary of the immunological data on the am mutants

\begin{tabular}{|c|c|c|c|}
\hline $\begin{array}{l}\text { Neurospora } \\
\text { mutant }\end{array}$ & $\begin{array}{c}\text { Enzyme } \\
\text { studies }\end{array}$ & $\begin{array}{c}\text { Double-diffusion } \\
\text { plates }\end{array}$ & $\begin{array}{l}\text { Immuno- } \\
\text { electrophoretic } \\
\text { plates }\end{array}$ \\
\hline$a m-1$ & + & + & + \\
\hline$a m-2$ & + & + & + \\
\hline$a m-3$ & + & + & + \\
\hline$a m-4$ & + & + & + \\
\hline$a m-5$ & - & - & - \\
\hline$a m-6$ & . & - & - \\
\hline$a m-7$ & . & + & + \\
\hline$a m-8$ & . & - & - \\
\hline$a m-\theta$ & . & - & - \\
\hline$a m-11$ & - & - & - \\
\hline$a m-12$ & . & + & + \\
\hline$a m-13$ & . & + & + \\
\hline$a m-14$ & . & - & - \\
\hline$a m-15$ & . & - & - \\
\hline$a m-16$ & . & - & - \\
\hline$a m-17$ & . & - & - \\
\hline$a m-18$ & . & - & - \\
\hline$a m-19$ & . & + & + \\
\hline
\end{tabular}

+ , Protein immunologically similar to wild-type, i.e. cross-reacting material; -, no protein immunologically similar to wild-type, i.e. no cross-reacting material.

by the serum is probably due to steric hindrance. Alternatively an antigenic site and the enzymatic site may coincide. If this be the case the site antibody complex and the site substrate complex should each be in a state of dynamic equilibrium to account for the residual enzyme activity in the presence of excess serum. It is hoped that current studies with univalent antibodies may distinguish between these hypotheses. 
The mutants have been studied by three techniques to test their immunological similarity with the wild-type protein. In all three methods there have been no contradictions to the conclusions drawn on the immunological relationship (Table 3). It is possible that some mutants which show cross-reacting material might show different types of cross-reaction on double-diffusion plates. The number of other lines on the plates may have obscured spur formation, except in three cases where purified $a m-1, a m-2$ and $a m-3$ extracts were tested against purified wild-type extracts and against each other. In these cases the cross-reaction appears to be complete. These three mutants therefore all have the same types of antigenic sites as the wild-type protein.

The immunological similarity between $a m-3$ and $a m-12$, and $a m-7$ and $a m-13$ agrees with the conclusions from crossing experiments (J. A. Pateman, unpublished results), enzyme experiments (Fincham, 1962) and complementation studies (J. A. Pateman, unpublished results) that $a m-12$ is a repeat occurrence of $a m-3$ and $a m-13$ a repeat of $a m-7$. In only one instance, that of $a m-14$, does a mutant which complements (D. R. Stadler, unpublished results) not show cross-reacting material (CRM). Dr J.R. S. Fincham has also failed to purify a mutant GDH protein from this mutant.

Specific stains for GDH and ADH show that the same anti-am ${ }^{+}$serum enzyme complex on the double-diffusion plates stains for both. This confirms the previous experiments of Bürk \& Pateman (1962) which showed the same protein to possess both these activities. Since the ADH anti-am ${ }^{+}$serum complex on the plate can be stained, the ADH activity, like the GDH activity, is not completely inhibited by the serum.

When a wild-type strain and a non-cross-reacting mutant, am-6, were grown on different supplemented media and on minimal media at higher temperatures it was shown that they still had the same cross-reacting pattern. This tends to weigh against the possibility that the production of the mutant protein is suppressed by the substrates L-glutamate and L-alanine, at least in the case of $a m-6$.

We wish to thank Mr C. B. Richards for his invaluable advice about immunological techniques. One of us (D. B. R.) wishes to acknowledge a grant from the Medical Research Council.

\section{REFERENCES}

Barratt, R. W. (1962). Altered proteins produced by mutation at the amination (am) locus in Neurospora. Genetics, 47, 941.

Bürk, R. R. \& Pateman, J. A. (1962). Glutamic and alanine dehydrogenase determined by one gene in Neurospora crassa. Nature, Lond. 196, 450.

Coombs, R. R. A., Richards, C. B. \& DodD, B. (1963). Serological identification of seminal stains. Medicine, Science and the Law, 3, 65.

Fincham, J. R. S. (1959). The role of chromosomal loci in enzyme formation. Proc. $X$ int. Congr. Genetics, 1, 355.

Fincham, J. R. S. (1962). Genetically determined forms of glutamic dehydrogenase in Neurospora crassa. J. molec. Biol. 4, 257.

Grabar, P. \& Williams, C. A., Jun. (1955). Méthode immunoélectrophoretique d'analyse des mélanges de substances antigéniques. Biochim. biophys. Acta, 17, 67.

Lowry, O. H., Rosebrough, N. J., Farr, N. J. \& Randall, R. J. (1951). Protein measurement with the Folin phenol reagent. J. biol. Chem. 193, 265. 
Journal of General Microbiology, Vol. 34, No. 2

Plate 1
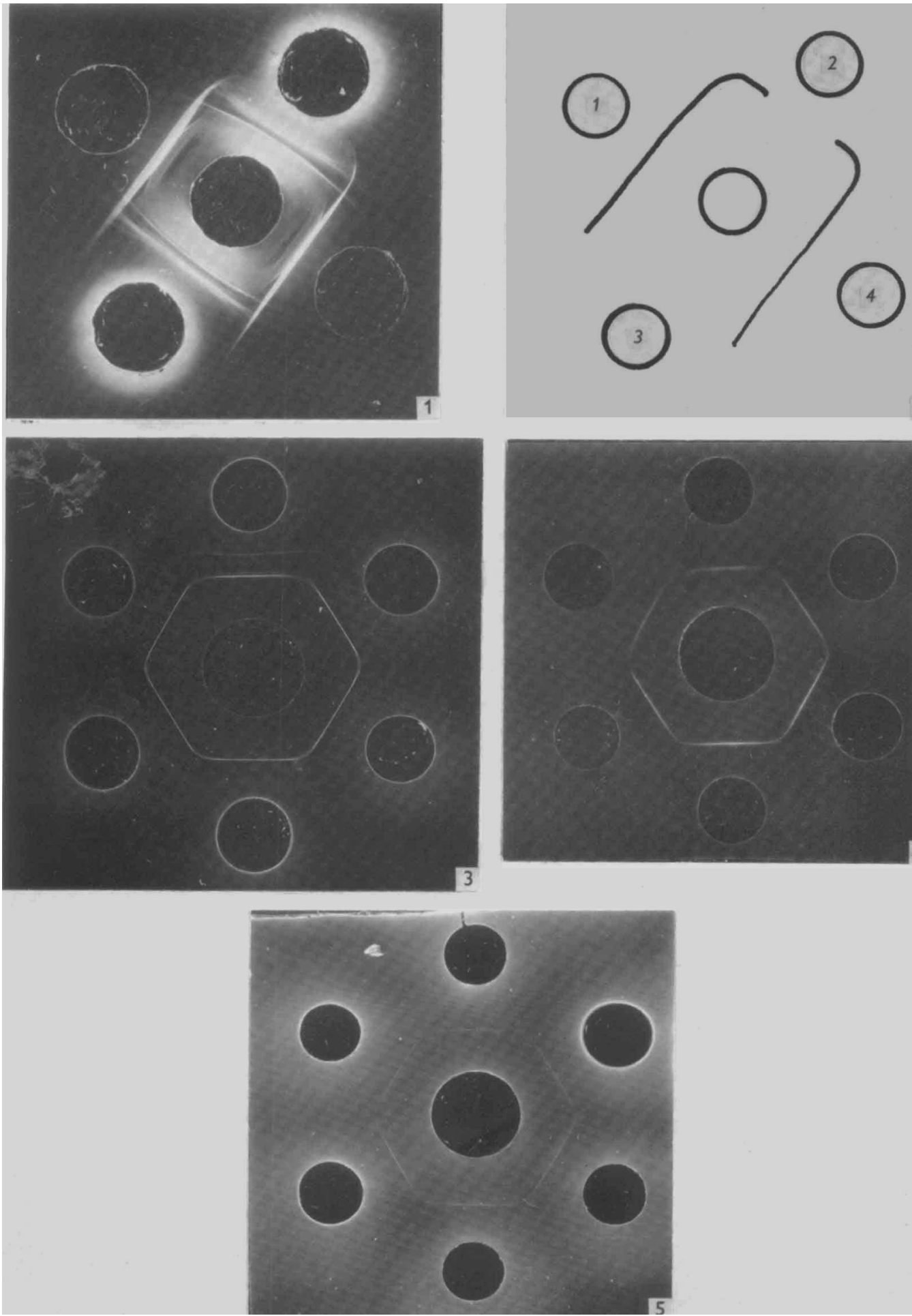

D. B. ROBER'TS AND J. A. PA'TEMAN 
Markert, C. L. \& Møluer, F. (1959). Multiple forms of enzymes: tissue, ontogenetic, and species specific patterns. Proc. nat. Acad. Sci., Wash. 45, 753.

Ouchterloney, Ö. (1953). Antigen antibody reactions in gel. Acta path. microbiol. scand. 32, 231.

Pateman, J. A. (1959). The effect of selection on ascospore size in Neurospora crassa. Heredity, 13, 1.

Sanwal, B. D. \& Lata, M. (1962). The regulation of glutamic dehydrogenase and an antigenically related protein in amination deficient mutants of Neurospora. Archs. Biochem 98, 420 .

\section{EXPLANATION OF PLATE}

Fig. 1. The centre well was filled with serum B-1-6. Wells 1 and 4 were filled with purified GDH, well 2 with crude extract of wild-type Neurospora crassa and well 3 with a crude extract of mutant $a m-11$. The dominant line in the purified extracts is the GDH anti- $a m^{+}$serum line and is present in the wild-type but is absent in the mutant. $\times 1 \frac{1}{2}$.

Fig. 2 is a schematic representation of Fig. 1 identifying the wells and illustrating the dominant purified GDH line. $\times 1 \frac{1}{2}$.

Fig. 3. The centre well contains a purified extract of Neurospora GDH and the six outside wells anti-am ${ }^{+}$serum C-1-3. The plate was stained for all proteins with amido schwarz. $\times 1 \frac{1}{2}$.

Fig. 4 was set up as Fig. 3 but stained for GDH activity. $\times 1 \frac{1}{2}$.

Fig. 5 was set up as Fig. 3 but stained for ADH activity. $\times 1 \frac{1}{2}$. 